Article

\title{
Determination of Metals' Content in Components Mounted on Printed Circuit Boards from End-of-Life Mobile Phones
}

\author{
Tadeusz Gorewoda ${ }^{1, *} *$, Marcus Eschen ${ }^{2}$, Jadwiga Charasińska ${ }^{1}$, Magdalena Knapik ${ }^{1}$, \\ Sylwia Kozłowicz ${ }^{1}$, Jacek Anyszkiewicz ${ }^{1}$, Michał Jadwiński ${ }^{1}$, Martyna Potempa ${ }^{1}$, \\ Marta Gawliczek ${ }^{1}$, Andrzej Chmielarz ${ }^{1}$ and Witold Kurylak ${ }^{1}$ \\ 1 Łukasiewicz Research Network-Institute of Non-Ferrous Metals, Sowińskiego 5, 44-121 Gliwice, Poland; \\ jadwigach@imn.gliwice.pl (J.C.); magdalenak@imn.gliwice.pl (M.K.); sylwiak@imn.gliwice.pl (S.K.); \\ jacekan@imn.gliwice.pl (J.A.); michalj@imn.gliwice.pl (M.J.); martyna.potempa@imn.gliwice.pl (M.P.); \\ martag@imn.gliwice.pl (M.G.); andrzejch@imn.gliwice.pl (A.C.); witoldk@imn.gliwice.pl (W.K.) \\ 2 Aurubis AG, Kupferstrasse 23, D-44532 Lünen, Germany; m.eschen@aurubis.com \\ * Correspondence: tadeusz.gorewoda@imn.gliwice.pl; Tel.: +48-322-380-278
}

Received: 20 August 2020; Accepted: 7 September 2020; Published: 9 September 2020

\begin{abstract}
The electronic components mounted on the printed circuit boards (PCBs) of mobile phones represent a resource that is rich in metals, and after separation from the boards, these components could be considered secondary raw materials. The concentrations of the valuable metals are insignificant when compared with those of complete PCBs; however, they could be significantly higher in a fraction formed from the separated components. This study focused on the analysis of $\mathrm{Ag}, \mathrm{Au}, \mathrm{Cu}, \mathrm{Nd}, \mathrm{Nb}$, $\mathrm{Ni}, \mathrm{Pb}, \mathrm{Pd}, \mathrm{Sn}$, and Ta in fractions produced by the separation of all the components mounted on PCBs from several types of mobile phones. Atomic absorption spectrometry, atomic emission spectrometry, and mass spectrometry techniques were utilized, and a comparison of five older models of "brick" phones and five modern smartphones was conducted. Additionally, $50 \mathrm{~kg}$ of PCBs from the current recycling market were analyzed in the same way to create a summary of the current recycling stream.
\end{abstract}

Keywords: WEEE; PCB; mobile phones; metals; analysis

\section{Introduction}

The past few decades have brought about a significant increase in the number of electronic devices worldwide. The mobile phone market is currently one of the most dynamically growing markets. In 2014, it was forecasted that this market could reach a level exceeding 6.9 billion specimens, with approximately two billion specimens considered as end-of-life products [1]. The sheer volume of products in this market has resulted in a growing interest by recycling companies to properly dispose of these devices. Modern recycling processes are typically based on the pyrometallurgical recovery of $\mathrm{Cu}, \mathrm{Au}, \mathrm{Ag}, \mathrm{Ni}, \mathrm{Pb}$, and $\mathrm{Sn}$ from waste consisting of the printed circuit boards (PCBs) of mobile phones. Other materials (e.g., plastic covers, batteries, and displays) are processed separately. Such a situation makes mobile phone waste material an interesting subject for analysis. A large collection of mobile phones was analyzed by Christian et al., in which over 80 [2] and 29 models [3] of mobile phones were analyzed, predominately by inductively coupled plasma optical emission spectrometry (ICP-OES). Twenty-six elements were taken into consideration. Many of them, including the most precious elements $(\mathrm{Au}$ and $\mathrm{Pt})$, were present in complete mobile phones at a level of approximately 100 ppm. Owing to the Roadmap to a Resource Efficient Europe by the European Commission [4], a critical review of electronic waste was necessary. Therefore, based on literature, estimations of the quantities of key metals found in the waste of mobile phones were summarized by Chancerel [5]. 
An analysis of smartphones revealed that the main precious metals that were found were $\mathrm{Au}$ and $\mathrm{Co}$, while others, namely, In, Ge, REE (rare earth elements), Ta, Sn, Pd, and Ag, were present but had less economic value. As expected, PCBs contained the majority of heavy metals when compared with those present in the displays and housings; however, because of the Restriction of Hazardous Substances (RoHS) Directive of the European Union [6], $\mathrm{Hg}$ and $\mathrm{Cd}$ are no longer present in the boards [7]. Additionally, an analysis of mobile phones was necessitated by the potentially hazardous characteristics found in their waste. A study conducted by Hira et al. focused on potentially toxic leachates produced via leaching procedures and waste extraction tests [8]. A range of metals, including $\mathrm{Pb}$ and $\mathrm{Cd}$, was found in the leachates. PCBs extracted from mobile phones that are still complete have been an interesting focus of studies, as they could be considered a specific type of recycling material in the market. Generally, 40-63\% of the total mass of PCBs consists of metals, while ceramics comprise $24-30 \%$ and polymers comprise $13-30 \%[9,10]$. We observed that the compositions of PCBs varied with their dates of production. However, we concluded that $\mathrm{Cu}$ presented the highest metal contribution at $16-34 \%$, while $\mathrm{Fe}, \mathrm{Ni}, \mathrm{Al}, \mathrm{Sn}, \mathrm{Pb}$, and $\mathrm{Zn}$ were found at few percentage levels of concentration. Additionally, smaller amounts of other elements, such as $\mathrm{Au}, \mathrm{Pd}$, and $\mathrm{Ag}$ (at the level of hundreds and thousands ppm), were observed [9-12]. Recently, a complex analysis of PCBs was conducted in Brazil, utilizing ICP-OES and three leaching media for the particles of PCBs, and it confirmed that the main economic value could still be observed in precious metals (approximately 80\%) [13].

Because $\mathrm{Au}$ and $\mathrm{Ag}$ are considered potential sources of economic value, their contents have been determined in several types of mobile phones by Vats and Singh [14]. It was established that the Au content was in the range of 0.009 to $0.0017 \%$, and $\mathrm{Ag}$ was in the range of 0.25 to $0.79 \%$. Such quantities are acceptable for large scale processes of pyro-metallurgical recovery in recycling companies. However, faster, inexpensive, and more selective methods could be developed if higher concentrations of Au and other metals were achieved. This could be accomplished by the removal of bare PCBs, which contain a large fraction of organic and silicate materials, as well as $\mathrm{Cu}$. The European project ADIR (Next generation urban mining-Automated disassembly, separation and recovery of valuable materials from electronic equipment) was focused on the development of technology for the effective extraction of valuable components from PCBs, as well as the hydrometallurgical processing of the resulting fractions [15]. Such an approach requires a separate analysis of the electronic components mounted on PCBs (e.g., capacitors, processors, resistors). The analysis can be done independently for each component using Laser Inductive Breakdown Spectroscopy, which is a fast, multielement technique capable of precisely targeting specific components $[16,17]$. An analysis of individual components can be used for the selection of components, which can then be extracted separately. However, to assess the economic potential of the components mounted on the PCBs, as well as the determination of a balance in the recovery processes, a complex analysis of the fractions produced by the extraction of all the components is essential. Therefore, in this study, we conducted an analysis of the components extracted from the waste of PCBs from the actual recycling market in 2018 to evaluate the concentrations that can currently be attained. Additionally, five models of older "brick" mobile phones and five models of smartphones were selected for a comparison of the concentrations of the most valuable elements in the fraction of components. Inductively coupled plasma mass spectrometry, atomic absorption spectrometry, and ICP-OES were used to determine the content of $\mathrm{Ag}, \mathrm{Au}, \mathrm{Cu}, \mathrm{Nd}, \mathrm{Ni}, \mathrm{Pb}, \mathrm{Pd}, \mathrm{Sn}, \mathrm{Ta}$, as well as other elements.

\section{Results and Discussion}

As was planned, PCBs from five models of older phones (coded as MPH-1 to MPH-5), five models of smartphones (coded as SMPH-1 to SMPH-5), as well as mixed waste from a real recycling stream (MPH-W) were analyzed in a quantitative way (see Materials and methods Section).

Separating the $50 \mathrm{~kg}$ of MPH-W PCBs yielded $12 \mathrm{~kg}$ of the fraction of components. It should be noted that the vibration alert motors of the phones were not typically mounted on the boards. Therefore, they were generally not included in the fraction. In a few specimens, they were soldered 
to the PCBs and extracted with the other components. The analysis of this fraction was the most comprehensive because of the large volume of material. It included the quantitative determination of 20 elements of interest. This sample provided the most representative composition of the current recycling stream. The results are presented in Tables 1 and 2 .

Table 1. Concentrations of selected elements produced by the extraction of all components from the mobile phone waste (MPH-W) of printed circuit boards (PCBs).

\begin{tabular}{|c|c|c|c|c|c|c|c|c|c|}
\hline Ag & $\mathrm{Au}$ & Co & $\mathrm{Cu}$ & $\mathbf{F e}$ & $\mathrm{Ga}$ & $\mathrm{Ge}$ & In & La & $\mathrm{Nb}$ \\
\hline \multicolumn{10}{|c|}{$(\%)$} \\
\hline 0.83 & 0.29 & 0.072 & 19.3 & 6.74 & 0.016 & 0.0068 & 0.001 & 0.059 & 0.0053 \\
\hline $\mathrm{Nd}$ & $\mathrm{Ni}$ & $\mathrm{Pb}$ & $P d$ & $\operatorname{Pr}$ & Sn & Si & Ta & $\mathbf{W}$ & $\mathrm{Zn}$ \\
\hline \multicolumn{10}{|c|}{$(\%)$} \\
\hline 0.66 & 3.46 & 1.53 & 0.048 & 0.07 & 5.53 & 10.2 & 0.27 & 0.22 & 1.55 \\
\hline
\end{tabular}

Table 2. Concentrations of selected elements in the residual bare PCBs of MPH-W.

\begin{tabular}{cccccccccc}
\hline $\mathbf{A g}$ & $\mathbf{A u}$ & $\mathbf{A l}$ & $\mathbf{C u}$ & $\mathbf{C a}$ & $\mathbf{N i}$ & $\mathbf{P b}$ & $\mathrm{Sn}$ & $\mathrm{Si}$ & $\mathbf{Z n}$ \\
\hline \multicolumn{8}{c}{$\mathbf{( \% )}$} \\
0.07 & 0.017 & 3.30 & 38.8 & 8.00 & 0.46 & 0.25 & 1.03 & 7.80 & 0.42 \\
\hline
\end{tabular}

The residual bare PCBs of the MPH-W were ground and analyzed as well. Significant amounts of $\mathrm{Cu}$, as well as some $\mathrm{Ag}$ and $\mathrm{Au}$, were revealed; however, epoxy laminate contributed substantially to the overall mass, which indicated that it could potentially qualify as a raw material for pyrometallurgical processing.

Because of a smaller volume of materials from older MPHs and modern SMPHs, only certain elements that presented potential economic value and were meaningful from a recovery standpoint were selected for analysis. Table 3 shows the content of $\mathrm{Au}, \mathrm{Ag}, \mathrm{Cu}, \mathrm{Zn}, \mathrm{Sn}, \mathrm{Pb}, \mathrm{Ni}, \mathrm{Co}, \mathrm{Ta}, \mathrm{Nd}$, and Nb from all of the MPHs and SMPHs that were amassed and compared with MPH-W to determine any existing correlations and trends. As shown in Table 3, the ratios of the metal content of the components to the total metal mass $(\mathrm{R})$ were calculated. Certain metals, such as $\mathrm{Co}, \mathrm{Ta}, \mathrm{Nd}$, and $\mathrm{Nb}$, were found in the fraction of components only. 
Table 3. Content of analyzed elements in older mobile phones (MPH), smartphones (SMPH), and mixed PCBs of mobile phones waste (MPH-W) as determined in the bare PCBs (B) and in the components (C), with the ratios of the metal content in components to the total metal mass (R). The results are presented in reference to a single specimen of mobile phone for each model.

\begin{tabular}{|c|c|c|c|c|c|c|c|c|c|c|c|c|c|c|c|c|}
\hline & \multirow[b]{2}{*}{$\begin{array}{l}\text { Production } \\
\text { Year }\end{array}$} & \multicolumn{3}{|c|}{$\mathrm{Au}$} & \multicolumn{3}{|c|}{$\mathrm{Ag}$} & \multicolumn{3}{|c|}{$\mathrm{Cu}$} & \multicolumn{3}{|c|}{$\mathrm{Zn}$} & \multicolumn{3}{|c|}{ Sn } \\
\hline & & $\begin{array}{c}\text { B } \\
\text { mg }\end{array}$ & $\begin{array}{c}\mathrm{C} \\
\mathrm{mg}\end{array}$ & $\mathbf{R}$ & $\begin{array}{c}\text { B } \\
\text { mg }\end{array}$ & $\begin{array}{c}\mathrm{C} \\
\mathrm{mg}\end{array}$ & $\mathbf{R}$ & $\begin{array}{c}\text { B } \\
\text { mg }\end{array}$ & $\begin{array}{c}\mathrm{C} \\
\mathrm{mg}\end{array}$ & $\mathbf{R}$ & $\begin{array}{c}\text { B } \\
\text { mg }\end{array}$ & $\begin{array}{c}\mathrm{C} \\
\mathrm{mg}\end{array}$ & $\mathbf{R}$ & $\begin{array}{c}\text { B } \\
\text { mg }\end{array}$ & $\begin{array}{c}\mathrm{C} \\
\mathrm{mg}\end{array}$ & $\mathbf{R}$ \\
\hline MPH-1 & 1999 & 3.68 & 18.01 & $83 \%$ & 6.13 & 100.5 & $94 \%$ & 5147 & 1030 & $17 \%$ & 10.3 & 182.2 & $95 \%$ & 135 & 377 & $74 \%$ \\
\hline MPH-2 & 2001 & 2.35 & 22.21 & $90 \%$ & 3.52 & 89.63 & $96 \%$ & 4574 & 454 & $9 \%$ & 5.87 & 49.90 & $89 \%$ & 162 & 539 & $77 \%$ \\
\hline MPH-3 & 2001 & 1.17 & 11.87 & $91 \%$ & 7.04 & 29.32 & $81 \%$ & 4515 & 408 & $8 \%$ & 8.21 & 38.74 & $83 \%$ & 161 & 53 & $25 \%$ \\
\hline MPH-4 & 2001 & 1.18 & 12.64 & $91 \%$ & 5.89 & 38.99 & $87 \%$ & 4630 & 397 & $8 \%$ & 7.06 & 35.02 & $83 \%$ & 160 & 263 & $62 \%$ \\
\hline МРH-5 & 2002 & 1.25 & 11.60 & $90 \%$ & 3.75 & 32.55 & $90 \%$ & 5438 & 337 & $6 \%$ & $<0.01$ & 40.75 & $100 \%$ & 78.8 & 210 & $73 \%$ \\
\hline SMPH-1 & 2012 & 0.23 & 7.67 & $97 \%$ & 1.87 & 14.01 & $88 \%$ & 2099 & 630 & $23 \%$ & 36.5 & 60.4 & $62 \%$ & 175 & 226 & $56 \%$ \\
\hline SMPH-2 & 2012 & 0.27 & 8.77 & $97 \%$ & 2.61 & 80.84 & $97 \%$ & 6557 & 675 & $9 \%$ & 2.15 & 41.95 & $95 \%$ & 238 & 377 & $61 \%$ \\
\hline SMPH-3 & 2014 & 0.19 & 10.10 & $98 \%$ & 5.55 & 52.84 & $90 \%$ & 3536 & 592 & $14 \%$ & 7.37 & 23.90 & $76 \%$ & 284 & 240 & $46 \%$ \\
\hline SMPH-4 & 2014 & 0.34 & 5.71 & $94 \%$ & 2.55 & 22.83 & $90 \%$ & 4022 & 2458 & $38 \%$ & 2.34 & 25.02 & $91 \%$ & 225 & 216 & $49 \%$ \\
\hline SMPH-5 & 2014 & 0.41 & 3.06 & $88 \%$ & 3.19 & 54.91 & $95 \%$ & 7645 & 766 & $9 \%$ & 18.9 & 20.2 & $52 \%$ & 315 & 235 & $43 \%$ \\
\hline \multirow[t]{3}{*}{ MPH-W } & 2018 * & 1.88 & 12.04 & $87 \%$ & 7.43 & 95.50 & $93 \%$ & 4160 & 801 & $16 \%$ & 45.0 & 64.4 & $59 \%$ & 110 & 230 & $68 \%$ \\
\hline & \multirow{2}{*}{$\begin{array}{l}\text { Production } \\
\text { Year }\end{array}$} & \multicolumn{3}{|c|}{$\mathbf{P b}$} & \multicolumn{3}{|c|}{$\mathrm{Ni}$} & Co & & $\mathrm{Ta}$ & & $\mathrm{Nd}$ & & $\mathrm{Nb}$ & & Pd \\
\hline & & $\begin{array}{c}\text { B } \\
\text { mg }\end{array}$ & $\begin{array}{c}\mathrm{C} \\
\mathrm{mg}\end{array}$ & $\mathbf{R}$ & $\begin{array}{c}\text { B } \\
\text { mg }\end{array}$ & $\begin{array}{c}\mathrm{C} \\
\mathrm{mg}\end{array}$ & $\mathbf{R}$ & $\begin{array}{c}\mathrm{C} \\
\mathrm{mg}\end{array}$ & & $\begin{array}{c}\mathrm{C} \\
\mathrm{mg}\end{array}$ & & $\begin{array}{c}\mathrm{C} \\
\mathrm{mg}\end{array}$ & & $\begin{array}{c}\mathrm{C} \\
\mathrm{mg}\end{array}$ & & $\begin{array}{c}\mathrm{C} \\
\mathrm{mg}\end{array}$ \\
\hline MPH-1 & 1999 & 82.1 & 236.3 & $74 \%$ & 78.4 & 279.2 & $78 \%$ & 3.27 & & 34.33 & & 131.0 & & 1.18 & & 6.70 \\
\hline MPH-2 & 2001 & 99.7 & 278.3 & $74 \%$ & 138.4 & 245.3 & $64 \%$ & 2.40 & & 27.37 & & 91.25 & & 1.04 & & 9.22 \\
\hline MPH-3 & 2001 & 97.4 & 60.4 & $38 \%$ & 239.4 & 165.4 & $41 \%$ & 1.15 & & 11.17 & & 53.40 & & 0.38 & & 5.24 \\
\hline MPH-4 & 2001 & 96.5 & 137.5 & $59 \%$ & 251.9 & 155.2 & $38 \%$ & 1.08 & & 2.74 & & 58.48 & & 0.69 & & 3.50 \\
\hline MPH-5 & 2002 & 110.0 & 103.6 & $48 \%$ & 57.5 & 99.6 & $63 \%$ & 0.85 & & 9.91 & & 24.62 & & 5.38 & & 1.58 \\
\hline SMPH-1 & 2012 & 4.38 & 4.67 & $52 \%$ & 32.8 & 260.5 & $89 \%$ & 4.67 & & 9.01 & & 5.67 & & 0.25 & & 1.40 \\
\hline SMPH-2 & 2012 & 1.20 & 4.19 & $78 \%$ & 39.3 & 316.5 & $89 \%$ & 2.67 & & 21.74 & & 19.83 & & 0.50 & & 0.50 \\
\hline SMPH-3 & 2014 & 4.22 & 0.54 & $11 \%$ & 56.2 & 304.6 & $84 \%$ & 3.06 & & 28.27 & & 0.94 & & 0.07 & & 0.34 \\
\hline SMPH-4 & 2014 & 2.99 & $<0.01$ & $0 \%$ & 112.8 & 193.2 & $63 \%$ & 8.34 & & 12.29 & & 0.79 & & 0.04 & & 0.44 \\
\hline SMPH-5 & 2014 & 0.75 & $<0.01$ & $0 \%$ & 31.3 & 159.1 & $84 \%$ & 2.32 & & 0.97 & & 0.60 & & 0.26 & & 0.15 \\
\hline MPH-W & 2018 * & 26.8 & 63.5 & $70 \%$ & 49.3 & 143.7 & $74 \%$ & 2.99 & & 4.15 & & 27.40 & & 0.21 & & 2.08 \\
\hline
\end{tabular}


Based on the results, it was observed that the content of elements in MPH-W corresponded mostly with the contents of the elements in older MPHs rather than SMPHs. These results were likely caused by typical behavior, in that people often consider SMPHs more valuable, thus keeping them even when they are no longer using them. By the end of 2018, the main constituents of the MPH-W were models that were produced in the first years of the 21st century, indicating that the period between production and final collection as waste was approximately fifteen years or more. It should be expected that older MPHs will still be present in the current waste stream for the next several years.

Gold, which is the most valuable element found in phones, was present in all of the mobile phones. However, the mass of Au was higher in the MPHs than in the SMPHs. The main portion of Au was found in the fraction of components, while residual amounts of Au were observed in bare PCBs, mainly in the coatings of connectors. Despite a decrease in the total mass of Au in the newer SMPHs, a stable ratio of distribution of $\mathrm{Au}$ between the PCBs and components was observed regardless of the production year. Only $10 \%$ of the total mass of Au was in the PCBs, while approximately $90 \%$ was found in the fraction of components; therefore, the fraction of components could be considered the main source of Au.

Silver, the second most valuable metal, was found to have a higher mass than Au. However, the same trends were observed in that $90 \%$ of the Ag content was in the components, and there were lower Ag contents in the SMPHs that were produced later. We observed that a Sn-Ag solder was used in newer SMPHs in place of $\mathrm{Sn}-\mathrm{Pb}$, which was a result of the RoHS Directive [6], while capacitors containing yellow Ta-Ag were found in older MPHs.

Copper was the only metal that was present in larger amounts in bare PCBs than in the components. The total mass of $\mathrm{Cu}$ depended on the model of the phone. There were no trends observed, and the same $\mathrm{Cu}$ content levels were recorded in the MPHs and SMPHs.

Zinc exhibited a low concentration, indicating that a separate recovery of $\mathrm{Zn}$ was not feasible. However, $\mathrm{Zn}$ has been recovered in the pyrometallurgical processing of PCBs associated with the $\mathrm{Cu}$ recovery process. The majority of the $\mathrm{Zn}$ was present in the fraction of components, and a gradual decrease in content was observed from the MPHs to the SMPHs.

Tin is typically recovered from electronic waste as a byproduct of metallurgical processing because great volumes of it are used for soldering. The Sn content was similar in both the MPHs and SMPHs; however, significant differences were noted in the $\mathrm{R}$ factor. More Sn was found on the bare PCBs in the SMPHs when compared with those in the MPHs. This probably resulted from the soldering technology that was utilized. In older MPHs, many components were soldered in a traditional way, whereas in modern SMPHs, all the components were fixed to the PCBs by surface mount technology (SMT). After unsoldering the SMT components, the majority of the solder remained on the boards; in the case of the MPHs, the solder was typically removed with the components.

Lead is another metal that was recovered from the waste of electronic devices because of the high content of $\mathrm{Sn}-\mathrm{Pb}$ solders present in them. Because of restrictions stated in the RoHS Directive in 2013 [6], there has been a significant decrease in the content of $\mathrm{Pb}$ in devices for each subsequent year of production. $\mathrm{Pb}$ has been almost entirely eliminated from modern SMPHs, and this element should not be present in future electronic waste. Being a solder constituent, it was split between bare PCBs and the fraction of components at a ratio that depended on the model of the phone.

Nickel was primarily found in the components, as approximately $60-80 \%$ of the total Ni content of the PCBs was present there. With regards to the Ni content in MPHs and SMPHs, no trends were observed, and the content of Ni should remain stable in future MPH-W.

Cobalt is a metal that is present in batteries [18] rather than in PCBs. Considering the increasing importance of this metal, the small amounts of Co that were present in the fraction of components should be considered for recovery during the processing of other materials that contain larger amounts of Co.

Tantalum is a metal recovered mainly from Ta capacitors. We determined that some of the older MPHs and some of the SMPHs had a significant mass of Ta. This resulted from the application of 
specific components that contained large amounts of this element, such as the Ta capacitors mounted in the MPHs. Ta accounted for approximately $20 \%$ of the total content of each capacitor in the MPHs; however, they have been replaced with polymer capacitors in SMPHs. Another component containing large amounts of Ta is constituted by surface acoustic wave (SAW) filters (10\% or more of Ta), as several of them can be found in the PCBs of all SMPHs.

Neodymium (belonging to the lanthanide series) plays an essential role in the production of magnets. It is mainly found in the speakers of mobile phones, and $\mathrm{Nd}$ comprises approximately $10 \%$ of such speakers [19]. However, some capacitors containing $\mathrm{Nd}$ were found in the fraction of components of MPHs. On the other hand, this metal was not observed in the PCBs of SMPHs; therefore, the main source for the recycling process could be the speakers.

Niobium is an expected element in MPH-W; however, a significant amount was not found in the examined models and materials. Additionally, the insignificant amounts that were observed decreased with the production years of all the mobile phones.

In the case of mobile phones' $\mathrm{PCBs}$, , platinum-group metals (PGM) were not significant constituents (see Table 3). Only a small amount of palladium was found in the components of PCBs from older mobile phones as constituents of palladium ceramic capacitors. In modern smartphones, only trace amounts of this metal were detected, so a decreasing trend may be expected in the next years.

\section{Materials and Methods}

\subsection{Materials for Analysis}

In this study, we analyzed $50 \mathrm{~kg}$ of assorted waste PCBs from the current recycling market. This included 2468 specimens of waste PCBs from various mobile phones (designated as MPH-W). To study changes over time, various models of modern smartphones (i.e., phones with large and color displays) were selected and analyzed; three models were produced in 2014 (SMPH-1, SMPH-2, and SMPH-3), two were produced in 2012 (SMPH-4 and SMPH-5), and each of the five mentioned models were from different manufacturers. Additionally, we analyzed five models of older brick phones; one produced in 1999 (MPH-1), three in 2001 (MPH-2, MPH-3, and MPH-4), and one in 2002 (MPH-5). The mobile phone models were coded as MPH or SMPH to protect the copyrights of the companies that produced these specific models. The general processing scheme is presented in Figure 1.

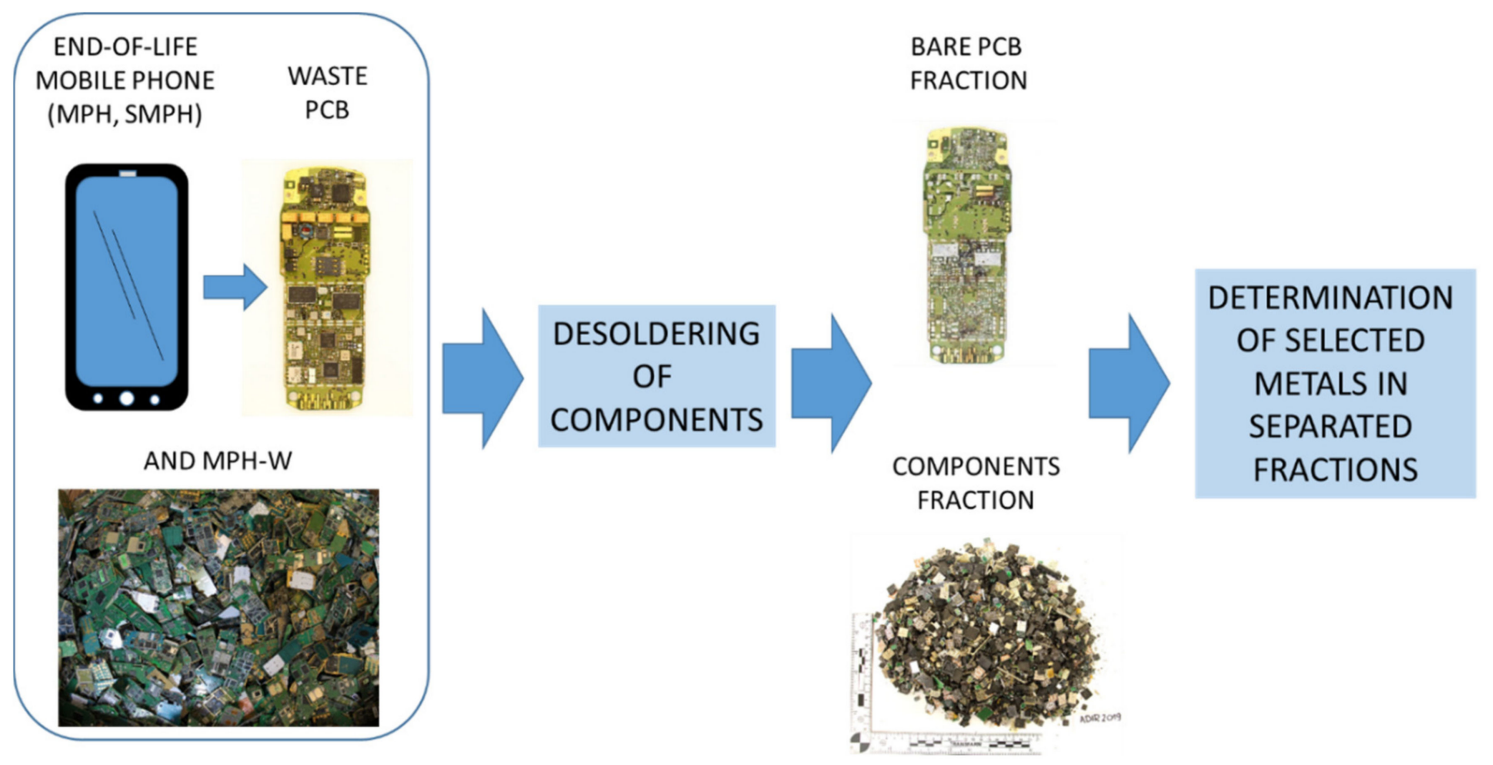

Figure 1. Scheme of material processing. 


\subsection{Preparation of Fraction of Components}

Complete mobile phones (both modern SMPHs and older MPHs) were dismantled manually, and the PCBs were extracted. The complete PCBs were heated to $230^{\circ} \mathrm{C}$, and then all the components were removed manually from their surfaces. The obtained fraction of components for the PCBs were then frozen in liquid nitrogen and ground in a cutting mill (PULVERISETTE 19, FRITSCH GmbH) to achieve grains less than $5 \mathrm{~mm}$ in size. The materials were then frozen again and ground in a vibrating cup mill (Pulverisette 9, Fritsch) to achieve fine-grains $(<90 \mu \mathrm{m})$.

\subsection{Sample Preparation and Analysis}

A multistage approach was taken when determining a standard sample preparation procedure for the analysis of $\mathrm{Au}, \mathrm{Sn}, \mathrm{Pb}, \mathrm{Nd}, \mathrm{Nb}, \mathrm{Ta}, \mathrm{Ga}, \mathrm{Ge}, \mathrm{In}, \mathrm{La}, \mathrm{Al}$, and $\mathrm{Ca}$ because of the variety of these elements, as well as their forms and concentrations. A sample $(0.5 \mathrm{~g})$ was calcined at $650{ }^{\circ} \mathrm{C}$ to remove the plastics ballast. Then, the calcined sample was treated with an acidic mixture of $\mathrm{HNO}_{3}$ and $\mathrm{HF}$ $(20 \mathrm{~mL}, 2: 1, v / v)$ to remove silicon from the sample matrix. The mixture was subsequently heated to evaporate the acids, and the residual was dissolved in $25 \mathrm{~mL}$ of aqua regia to dissolve the sample, including gold. The resulted mixture was filtered, and the undissolved residue was fused with $2.5 \mathrm{~g}$ of $\mathrm{Na}_{2} \mathrm{O}_{3}$ to oxidize this residue and allow the digestion of the produced sinter in $25 \mathrm{~mL}$ of aqua regia. The aqua regia solutions were merged and diluted with deionized water until the desired volume $(50 \mathrm{~mL}$ or $100 \mathrm{~mL}$ ) was achieved and were then analyzed by spectrometric methods.

For the analysis of $\mathrm{Ag}, \mathrm{Zn}, \mathrm{Ni}$, and $\mathrm{Cu}$, the calcined sample was treated with an acidic mixture

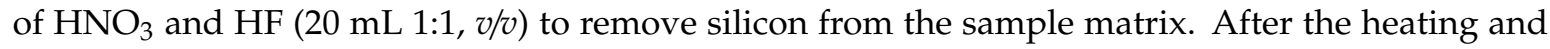
evaporation of the acids, the residue was treated with a mixture of $\mathrm{H}_{2} \mathrm{SO}_{4}$ and $\mathrm{HNO}_{3}(25 \mathrm{~mL}, 2: 3, v / v)$ for oxidation. Then, the mixture was heated and evaporated to remove sulfuric acid, and the residue was dissolved in $5 \mathrm{~mL} \mathrm{HNO}_{3}$. The solution was analyzed after diluting it to the desired volume $(50 \mathrm{~mL}$ or $100 \mathrm{~mL}$ ) with deionized water.

The prepared samples were analyzed quantitatively utilizing atomic absorption spectrometry, ICP-OES, or inductively coupled plasma mass spectrometry. The selection of the technique depended on the level of the analyte concentration.

The Si content was determined using the gravimetric method after treating the samples with aqua regia.

\section{Conclusions}

Our study focused on the analysis of the fraction of components, which was separated from the PCBs of mobile phones. This separation provided the potential to produce a fraction of components with higher concentrations of valuable metals after the removal of the relatively heavy bare PCBs. In this study, five older MPHs, five modern SMPHs, and assorted MPH-Ws from 2018 were processed. Components were extracted from their PCBs, and then both the components and residual bare PCBs were analyzed independently. The concentrations of 20 elements were determined quantitatively from the assorted waste in order to provide an overview of the potential recovery of elements and to assess the current recycling stream of mobile phones. Eleven metals were selected for a comparison between older MPHs and modern SMPHs, as well as a comparison with recycling waste, with respect to the masses of those metals and their contents in the fraction of components and bare PCBs. This allowed us to observe any differences that resulted from miniaturization, technology development, and/or decreasing production costs. A significant reduction was observed in the content of $\mathrm{Au}$, which was the most precious metal found in the waste. However, a stable ratio of 9:1 between the content of $\mathrm{Au}$ in the fraction of components and bare PCBs was observed. In such a situation, the same technology could be used for the processing of both older and modern mobile phones; however, a larger number of specimens from the PCBs of SMPHs must be processed in order to attain the same mass of recycled $\mathrm{Au}$. A number of metals with a potential economic value, such as $\mathrm{Ag}, \mathrm{Cu}, \mathrm{Zn}, \mathrm{Sn}$, and $\mathrm{Co}$, were recorded in 
similar amounts in both the older and modern mobile phones. Decreasing trends were noted for $\mathrm{Ni}, \mathrm{Nd}$, $\mathrm{Nb}$, and $\mathrm{Pb}$, and the latter was almost entirely eliminated in the SMPHs owing to the RoHS Directive. The results reported by the ADIR project [19] with respect to Ta indicated that the content of this metal has not changed significantly over time. Nevertheless, Ta was present in different components such as Ta capacitors and SAW filters. The observed mass of Ta was a good predictor for the future recovery of this element.

The separation of the electronic components from the PCBs of mobile phones could generate a new noteworthy fraction for the recovery of valuable metals. The elimination of epoxy resin ballast resulted in higher concentrations of the target metals and allowed for potentially new approaches for their recovery. However, one should take into account that technological progress in the production of mobile phones will simultaneously result in changes to the composition of future MPH-W.

Author Contributions: Conceptualization, T.G.; Data curation, T.G. and M.E.; Investigation, T.G., M.E., J.C., M.K., S.K. and J.A.; Methodology, T.G.; Project administration, T.G., A.C. and W.K.; Resources, M.J., M.P. and M.G.; Supervision, A.C.; Writing—original draft, T.G.; Writing—review \& editing, A.C. and W.K. All authors have read and agreed to the published version of the manuscript.

Funding: The authors express their thanks for the support and funding of the ADIR project by the European Commission. This project has received funding from the European Union's Horizon 2020 research and innovation programme under grant agreement No 680449.

Acknowledgments: Special thanks to the following members of the ADIR project team: R. Noll (Project Coordinator, Fraunhofer ILT), G. Benke (Łukasiewicz-Instytut Metali Nieżelaznych, Ł-IMN), M. Grzegorczyk (Ł-IMN), A. Hryniszyn (Ł-IMN), S. Kasierot (Ł-IMN), J. Kozłowski (Ł-IMN), K. Leszczyńska-Sejda (Ł-IMN), D. Lewandowski (Ł-IMN), I. Nabiałczyk (Ł-IMN), H. Brumm (H. C. Starck), C. Fricke-Begemann (Fraunhofer ILT), M. Bergamos (Electrocycling), C. Gehlen (Laser Analytical Systems \& Automation), M. Guolo (Osai), J. Makowe (Laser Analytical Systems \& Automation), G. Sellin (Electrocycling), A. Tori (Osai), and F. Veglia (Tre Tau Engineering).

Conflicts of Interest: The authors declare no conflict of interest.

\section{References}

1. IDC Corporate USA Statista. Available online: http:/de.statista.com/statistik/daten/studie/192704/umfrage/ absatz-von-mobiltelefonen-weltweit-seit-2006/ (accessed on 1 March 2020).

2. Christian, B.; Romanov, A.; Romanova, I.; Turbini, L.J. Elemental compositions of over 80 cell phones. J. Electron. Mater. 2014, 43, 4199-4213. [CrossRef]

3. Christian, B.; Romanova, I.; Turbini, L. Elemental compositions of over two dozen cell phones. In Proceedings of the IPC APEX EXPO 2012, San Diego, CA, USA, 28 February 2012; IPC: Bannockburn, IL, USA, 2012; Volume 1, pp. 275-295.

4. European Commission Roadmap to a Resource Efficient Europe. Communication from the Commision to the European Parliament, the Council and the European Economic and Social Committee and the Committee of the Regions. Eur. Comm. 2011, 571, 1-26.

5. Chancerel, P.; Marwede, M.; Nissen, N.F.; Lang, K.D. Estimating the quantities of critical metals embedded in ICT and consumer equipment. Resour. Conserv. Recycl. 2015, 98, 9-18. [CrossRef]

6. European Parliament. Directive 2011/65/EU of the European Parliament and of the Council, European Parliament L 174/88. Off. J. Eur. Union 2011, L 174, 88-110.

7. Maragkos, K.G.; Hahladakis, J.N.; Gidarakos, E. Qualitative and quantitative determination of heavy metals in waste cellular phones. Waste Manag. 2013, 33, 1882-1889. [CrossRef]

8. Hira, M.; Yadav, S.; Morthekai, P.; Linda, A.; Kumar, S.; Sharma, A. Mobile Phones-An asset or a liability: A study based on characterization and assessment of metals in waste mobile phone components using leaching tests. J. Hazard. Mater. 2018, 342, 29-40. [CrossRef] [PubMed]

9. Park, Y.J.; Fray, D.J. Recovery of high purity precious metals from printed circuit boards. J. Hazard. Mater. 2009, 164, 1152-1158. [CrossRef] [PubMed]

10. Yamane, L.H.; de Moraes, V.T.; Espinosa, D.C.R.; Tenório, J.A.S. Recycling of WEEE: Characterization of spent printed circuit boards from mobile phones and computers. Waste Manag. 2011, 31, 2553-2558. [CrossRef] [PubMed] 
11. Yang, T.; Xu, Z.; Wen, J.; Yang, L. Factors influencing bioleaching copper from waste printed circuit boards by Acidithiobacillus ferrooxidans. Hydrometallurgy 2009, 97, 29-32. [CrossRef]

12. Guo, J.; Guo, J.; Xu, Z. Recycling of non-metallic fractions from waste printed circuit boards: A review. J. Hazard. Mater. 2009, 168, 567-590. [CrossRef] [PubMed]

13. Terena, L.M.; Neto, A.F.D.A.; Gimenes, M.L.; Vieira, M.G.A. Characterisation of printed circuit boards of mobile phones discarded in Brazil. Chem. Eng. Trans. 2017, 56, 1945-1950. [CrossRef]

14. Vats, M.C.; Singh, S.K. Assessment of gold and silver in assorted mobile phone printed circuit boards (PCBs): Original article. Waste Manag. 2015, 45, 280-288. [CrossRef] [PubMed]

15. ADIR Project. Available online: www.adir.eu (accessed on 1 March 2020).

16. Noll, R.; Fricke-Begemann, C.; Connemann, S.; Meinhardt, C.; Sturm, V. LIBS analyses for industrial applications-an overview of developments from 2014 to 2018. J. Anal. At. Spectrom. 2018, 33, 945-956. [CrossRef]

17. Ángel Aguirre, M.; Hidalgo, M.; Canals, A.; Nóbrega, J.A.; Pereira-Filho, E.R. Analysis of waste electrical and electronic equipment (WEEE) using laser induced breakdown spectroscopy (LIBS) and multivariate analysis. Talanta 2013, 117, 419-424. [CrossRef] [PubMed]

18. Larouche, F.; Tedjar, F.; Amouzegar, K.; Houlachi, G.; Bouchard, P.; Demopoulos, G.P.; Zaghib, K. Progress and status of hydrometallurgical and direct recycling of Li-Ion batteries and beyond. Materials 2020, 13, 801. [CrossRef] [PubMed]

19. Noll, R.; Ambrosch, R.; Bergmann, K.; Britten, S.; Brumm, H.; Chmielarz, A.; Connemann, S.; Eschen, M.; Frank, A.; Fricke-Begemann, C.; et al. Next generation urban mining-Automated disassembly, separation and recovery of valuable materials from electronic equipment: Overview of R\&D approaches and first results of the European project ADIR. In Proceedings of the European Metallurgical Conference, EMC 2017, Leipzig, Germany, 25 June 2017; GDMB: Clausthal-Zellerfeld, Germany, 2017; Volume 2, pp. 799-816.

(C) 2020 by the authors. Licensee MDPI, Basel, Switzerland. This article is an open access article distributed under the terms and conditions of the Creative Commons Attribution (CC BY) license (http://creativecommons.org/licenses/by/4.0/). 